ISSN 1392-3196 / e-ISSN 2335-8947

Zemdirbyste-Agriculture, vol. 101, No. 3 (2014), p. 333-340

DOI 10.13080/z-a.2014.101.043

\title{
Assessment of genetic diversity of Latvian sea buckthorn (Hippophae rhamnoides L.) germplasm using molecular markers
}

\author{
Gunārs LĀCIS, Irita KOTA-DOMBROVSKA \\ Latvia State Institute of Fruit-Growing \\ Graudu 1, Dobele, Latvia \\ E-mail: gunars.lacis@1vai.lv
}

\begin{abstract}
Sea buckthorn (Hippophae rhamnoides L.) is becoming an interesting and promising crop in Latvia due to its high content of valuable nutrients and bioactive substances. Increasing horticultural use of sea buckthorn is stimulating also an interest in research and breeding of different sea buckthorn forms for fruit production. Plant material developed from crosses among $H$. rhamnoides ssp. mongolica, ssp. rhamnoides and ssp. fluviatilis was introduced as well as bred in Latvia to acquire locally well adapted and valuable cultivars. Utilization of available sea buckthorn plant material is dependent on the reasonable genetic diversity evaluation and plant material identification. Therefore 36 sea buckthorn accessions grown in Latvia were characterized using previously tested eight microsatellites or simple sequence repeat (SSR) and sixteen random amplified polymorphic DNA (RAPD) markers. Applied markers allowed complete discrimination of the tested sea buckthorn accessions, as well as determination of genetic similarity and relatedness. Some correlation between the cluster analysis of molecular data and the plant material origin and known pedigree was found, which demonstrated the suitability of the utilized markers for the characterization of sea buckthorn germplasm. Higher correspondence with known origin was stated for the set of RAPD markers, which discriminated sea buckthorn accessions according to the place of origin and breeding program. The two applied methods of molecular markers complemented each other and provided genetic information for the Latvian sea buckthorn breeders for development of further hybridization strategy as well as a basic tool for marker assisted selection.
\end{abstract}

Key words: genetic diversity, germplasm, Hippophae rhamnoides, microsatellites, RAPD.

\section{Introduction}

Sea buckthorn (Hippophae rhamnoides L.) (2n $=24)$ is a promising fruit crop in Latvia, due to valuable nutrients and bioactive substances including vitamins, fatty acids, free amino acids and elemental components. There were several attempts to introduce sea buckthorn in Latvia. Successful introduction of sea buckthorn was realized in the 1980's using cultivars developed from crosses among $H$. rhamnoides ssp. mongolica, ssp. rhamnoides and ssp. fluviatilis. Initial plant material was acquired from Prof. Tit Trofimov at Moscow State University. Local breeding of sea buckthorn cultivars was performed by Latvian breeders Andrejs Bruvelis and Karlis Blums, who continued to strengthen the adaptation of introduced cultivars by backcrosses with $H$. rhamnoides ssp. rhamnoides (Bruvelis, 2003; 2007). Several well adapted cultivars have been developed. Open pollinated elite seedlings selected at the M. A. Lisavenko Scientific Research Institute of Barnaul were also introduced for field evaluation and further utilization in growing and breeding. This germplasm represents a geographically distant group of sea buckthorn in comparison with the previously introduced material. As a result, the sea buckthorn plant material used in Latvia both for breeding and growing has geographically distant origin and high potential genetic variability. Therefore characterization and evaluation is an important and critical activity, which determines the success of further utilization efforts.

The identification of cultivars and assessment of breeding material could be performed on the basis of morphological and agronomic characteristics of plant material. In fruit crops, including sea buckthorn, these traits are associated with several important limiting factors: phenotypic characters are generally influenced by environment and the growth stage of the plant. It results in long and expensive evaluation during the whole vegetative growth period to obtain satisfactory morphological data for genetic diversity and relatedness evaluation. Therefore different molecular markers are very useful to distinguish between accessions and for investigations of genetic diversity or relatedness. Markers such as random amplified polymorphic DNA (RAPD) (Persson, Nybom, 1998; Jeppsson et al., 1999; 
Bartish et al., 2000; Ruan et al., 2004; Sheng et al., 2006; Singh et al., 2006; Sun et al., 2006), inter-simple sequence repeats (ISSR) (Tian et al., $2004 \mathrm{a} ; \mathrm{b}$ ), amplified fragment length polymorphism (AFLP) (Ruan, Li, 2005) and microsatellites or simple sequence repeats (SSR) (Wang et al., 2008; Lacis et al., 2014) have been applied in sea buckthorn species genetic diversity studies. The application of different molecular marker methods for characterization of plant material increases the value of the obtained information, but at the same time creates problems with interpretation of results and choice of the most appropriate ones.

The aim of the study was to compare usefulness of two molecular marker types in the characterization of sea buckthorn, and to characterize genetic diversity of sea buckthorn (Hippophae rhamnoides L.) grown in Latvia.

\section{Material and methods}

Plant material. Thirty six sea buckthorn (Hippophae rhamnoides L.) accessions grown in Latvia were used in the investigation carried out in 2011. All sea buckthorn accessions used in the investigation represent different level of inter-subspecies crosses among H. rhamnoides ssp. mongolica, ssp. rhamnoides and ssp. fluviatilis (Lacis et al., 2014), and includes cultivars widely grown in Latvia, local selections, introduced breeding material, wild samples or cultivation escapees as well as open pollinated elite seedlings selected at the M. A. Lisavenko Scientific Research Institute of Barnaul, which represents Altai (Siberia, Russia) type of sea buckthorn adapted to continental climate (Table 1).

Table 1. Accessions of the Latvian sea buckthorn collection

\begin{tabular}{|c|c|c|c|c|}
\hline No. & Accession name & $\begin{array}{c}\text { Country of } \\
\text { origin }\end{array}$ & $\begin{array}{c}\text { Accession } \\
\text { type }\end{array}$ & Description of accession \\
\hline 1 & 'Avgustinka' & Russia & A & MGU, selected sample from Leningrad region o.p. \\
\hline 2 & 'Botaniczeskaya Lubitelskaya' & Russia & A & MGU, selected sample from Leningrad region o.p. \\
\hline 3 & 'Edgars' & Latvia & $\mathrm{W}$ & unknown origin cultivated male plant \\
\hline 4 & H 1.1. & Russia & $\mathrm{B}$ & Barnaul, Altai type \\
\hline 5 & H 1.10 . & Russia & $\mathrm{B}$ & Barnaul, Altai type \\
\hline 6 & H 1.11. & Russia & $\mathrm{B}$ & Barnaul, Altai type \\
\hline 7 & H 1.12. & Russia & $\mathrm{B}$ & Barnaul, Altai type \\
\hline 8 & H 1.13. & Russia & $\mathrm{B}$ & Barnaul, Altai type \\
\hline 9 & H 1.14. & Russia & $\mathrm{B}$ & Barnaul, Altai type \\
\hline 10 & H 1.2. & Russia & $\mathrm{B}$ & Barnaul, Altai type \\
\hline 11 & H 1.3. & Russia & $\mathrm{B}$ & Barnaul, Altai type \\
\hline 12 & H 1.4. & Russia & B & Barnaul, Altai type \\
\hline 13 & H 1.5. & Russia & $\mathrm{B}$ & Barnaul, Altai type \\
\hline 14 & H 1.6. & Russia & B & Barnaul, Altai type \\
\hline 15 & H 1.7. & Russia & $\mathrm{B}$ & Barnaul, Altai type \\
\hline 16 & Н 1.8 . & Russia & $\mathrm{B}$ & Barnaul, Altai type \\
\hline 17 & Н 1.9. & Russia & $\mathrm{B}$ & Barnaul, Altai type \\
\hline 18 & Н 2.1 . & Russia & B & Barnaul, Altai type \\
\hline 19 & Н 2.2 . & Russia & $\mathrm{B}$ & Barnaul, Altai type \\
\hline 20 & Н 2.3. & Russia & $\mathrm{B}$ & Barnaul, Altai type \\
\hline 21 & H 3.1 . & Russia & B & Barnaul, Altai type \\
\hline 22 & H 3.2. & Russia & $\mathrm{B}$ & Barnaul, Altai type \\
\hline 23 & 'Lomonosovskaya' & Russia & $\mathrm{A}$ & MGU \\
\hline 24 & 'Luczistaya' & Russia & A & MGU \\
\hline 25 & 'Mary' & Latvia & A & 'Botaniczeskaya Lubitelskaya' o.p. \\
\hline 26 & 'Podarok Sadu' & Russia & A & MGU, selected sample from Leningrad region o.p. \\
\hline 27 & 'Prozracznaya' & Russia & A & MGU \\
\hline 28 & 'Sjurpriz Pribaltiki’ & Russia & A & Mitzcurinsk, selected sample from Kaliningrad region o.p. \\
\hline 29 & ‘Skibes siev’ & Latvia & W & unknown origin wild sample \\
\hline 30 & 'Skibes vir' & Latvia & $\mathrm{W}$ & unknown origin wild male sample \\
\hline 31 & 'Tatjana' & Latvia & A & 'Botaniczeskaya Lubitelskaya' o.p. \\
\hline 32 & 'Trofimovskaya' & Russia & A & MGU \\
\hline 33 & Vir 1 & Latvia & $\mathrm{B}$ & unknown origin cultivated male sample \\
\hline 34 & Vir 2 & Latvia & $\mathrm{B}$ & unknown origin cultivated male sample \\
\hline 35 & Vir 3 & Latvia & B & unknown origin cultivated male sample \\
\hline 36 & Vir 4 & Latvia & $\mathrm{B}$ & unknown origin cultivated male sample \\
\hline
\end{tabular}

A - advanced cultivar, B - breeding line, $\mathrm{W}$ - wild sample; Barnaul - open pollinated elite seedling selected at the M. A. Lisavenko Scientific Research Institute of Barnaul; MGU - variety originated by T. Trofimov at the Botanical Garden of Moscow State University; Mitzcurinsk - variety originated by V. T. Kondratov at the I. V. Mitzcurin Scientific Research Institute, Mitzcurinsk, o.p. - open pollinated 
Isolation of genomic deoxyribonucleic acid (DNA) and polymerase chain reaction (PCR) analysis. Total DNA from young leaves was isolated using a Genomic DNA purification kit ("Fermentas", Lithuania).

Simple sequence repeat (SSR) analysis. PCR reactions were performed in a $20 \mu \mathrm{L}$ reaction with $25 \mathrm{ng}$ DNA, $2 \mathrm{mM}$ each primer, $200 \mathrm{mM}$ of each nucleotide, $1.5 \mathrm{mM} \mathrm{MgCl}_{2}$ and $0.5 \mathrm{U}^{\mathrm{REDTaq}^{\circledR}} \mathrm{DNA}^{\circledR}$ polymerase ("Sigma", USA) per reaction, in the Eppendorf Mastercycler ep Gradient thermal cycler ("Eppendorf", Germany) for 40 cycles with denaturation at $95^{\circ} \mathrm{C}$ for $30 \mathrm{~s}$, annealing at $48,50,51^{\circ} \mathrm{C}$ for $30 \mathrm{~s}$ and extension at $72^{\circ} \mathrm{C}$ for $30 \mathrm{~s}$, with a final extension step of $10 \mathrm{~min}$ at $72^{\circ} \mathrm{C}$ (Wang et al., 2008). For SSR markers PCR products were first checked on $1 \%$ agarose gels in $1 \times$ TAE (Tris-acetateEDTA) buffer and visualized by staining with ethidium bromide to test for the presence of PCR products. The same PCR products were subsequently analyzed on a genetic analyzer ABI PRISM ${ }^{\circledR} 3100$ ("Applied Biosystems", USA) and genotyped using software GeneMapper ${ }^{\circledR}$ v4.0 (“Applied Biosystems", USA).

Random amplified polymorphic DNA (RAPD) analysis. RAPD profiles were generated by using 16 previously selected highly polymorphic 10 -mers (Table 2 ). PCR reactions were performed in $20 \mu \mathrm{L}$ final volume containing $15 \mathrm{ng}$ of DNA, $2 \mathrm{mM}$ of 10 -mer, $200 \mathrm{mM}$ of each nucleotide, $1.5 \mathrm{mM} \mathrm{MgCl}_{2}$ and $0.5 \mathrm{U} \mathrm{REDTaq}^{\circledR}$ DNA polymerase ("Sigma", USA). Amplifications

Table 2. Genotyping results for the Latvian sea buckthorn accessions using random amplified polymorphic DNA (RAPD) markers

\begin{tabular}{cccccc}
\hline RAPD primer & Sequence & $\begin{array}{c}\text { Total number of } \\
\text { bands }\end{array}$ & $\begin{array}{c}\text { Number of } \\
\text { polymorphic bands }\end{array}$ & $\begin{array}{c}\text { Percentage of } \\
\text { polymorphic bands }\end{array}$ & $\begin{array}{c}\text { Size range, } \\
\text { bp }\end{array}$ \\
\hline OPA-02 & TGCCGAGCTG & 3 & 2 & 66.6 & $270-780$ \\
OPA-03 & AGTCAGCCAC & 14 & 14 & 100 & $150-1050$ \\
OPA-08 & GTGACGTAGG & 10 & 10 & 100 & $220-1150$ \\
OPA-11 & CAATCGCCGT & 15 & 15 & 100 & $190-1400$ \\
OPA-18 & AGGTGACCGT & 9 & 9 & 100 & $180-1100$ \\
OPB-07 & GGTGACGCAG & 18 & 18 & 100 & $170-1400$ \\
OPB-09 & TGGGGGACTC & 10 & 10 & 100 & $170-1500$ \\
OPB-17 & AGGGAACGAG & 10 & 10 & 100 & $180-1100$ \\
OPD-02 & GGACCCAACC & 5 & 4 & 80 & $300-680$ \\
OPD-03 & GTCGCCGTCA & 16 & 16 & 100 & $200-1050$ \\
OPD-05 & TGAGCGGACA & 7 & 7 & 100 & $180-620$ \\
OPD-08 & GTGTGCCCCA & 23 & 23 & 100 & $150-1400$ \\
OPD-11 & AGCGCCATTG & 15 & 15 & 100 & $190-1050$ \\
OPD-13 & GGGGTGACGA & 4 & 4 & 100 & $350-610$ \\
OPD-18 & GAGAGCCAAC & 16 & 20 & 100 & $120-1150$ \\
OPD-20 & ACCCGGTCAC & 20 & & 100 & $170-1450$ \\
\hline
\end{tabular}

were carried out in gradient Eppendorf Mastercycler ep Gradient ("Eppendorf", Germany) thermal cycler under the following conditions: $94^{\circ} \mathrm{C}$ for $3 \mathrm{~min}$, followed by 45 cycles at $94^{\circ} \mathrm{C}$ for $30 \mathrm{~s}, 43^{\circ} \mathrm{C}$ for $1 \mathrm{~min}$, and $72^{\circ} \mathrm{C}$ for $1 \mathrm{~min}$. At the end an additional $7 \mathrm{~min}$ at $72^{\circ} \mathrm{C}$ was added. The amplification products were separated by electrophoresis in $2 \%$ agarose gels in $1 \times$ TAE buffer, visualized by staining with ethidium bromide, and documented under UV light with digital photography. Amplifications and scorings were repeated twice.

Data analysis. To ensure the comparison of two molecular marker types SSR and RAPD data were registered as 1 for the presence of a particular band and 0 for its absence and were transformed into the binary matrix. Marker characteristics were computed using the computer program GENALEX 6.1 (Peakall, Smouse, 2006). Nei and Li/Dice similarity index calculations
(Nei, Li, 1979) and UPGMA (unweighted pair group method with arithmetic mean) clustering was performed using FreeTree (Hampl et al., 2001) and presented using MEGA 6 (Tamura et al., 2013).

\section{Results and discussion}

Both molecular marker types used provided unique genotypes for all analyzed sea buckthorn accessions ensuring their identification. It was possible due to high level of marker polymorphism and subsequent discrimination power. The level of polymorphism for eight previously selected SSR markers (Lacis et al., 2014) was high, with the number of alleles identified ranging from 4 ( $\mathrm{HrOS}$ ) to 22 ( $\mathrm{HrO4}$ ) (average 10.25) (Table 3).

The number of effective alleles ranged from 2.653 (HrO5) to 8.945 (HrO4). Observed heterozygocity 
Table 3. Genotyping results for the Latvian sea buckthorn accessions using eight microsatellite (SSR) loci

\begin{tabular}{lcccccccc}
\hline & \multicolumn{1}{c}{ Loci } \\
\cline { 2 - 9 } & HrO1 & HrO2 & HrO3 & HrO4 & Hr05 & HrO6 & HrO7 & HrO8 \\
\hline Number of alleles & 14 & 10 & 10 & 22 & 6 & 5 & 11 & 4 \\
Number of effective alleles & 7.043 & 5.684 & 5.153 & 8.945 & 2.653 & 3.713 & 4.853 & 2.723 \\
Information index & 2.171 & 1.932 & 1.870 & 2.643 & 1.235 & 1.425 & 1.861 & 1.103 \\
Observed heterozygosity & 0.889 & 0.861 & 0.972 & 0.815 & 0.861 & 0.889 & 0.781 & 0.833 \\
Expected heterozygosity & 0.858 & 0.824 & 0.806 & 0.888 & 0.623 & 0.731 & 0.794 & 0.633 \\
Unbiased expected heterozygosity & 0.870 & 0.836 & 0.817 & 0.905 & 0.632 & 0.741 & 0.807 & 0.642 \\
Fixation index & -0.036 & -0.045 & -0.206 & 0.083 & -0.382 & -0.216 & 0.016 & -0.317 \\
\hline
\end{tabular}

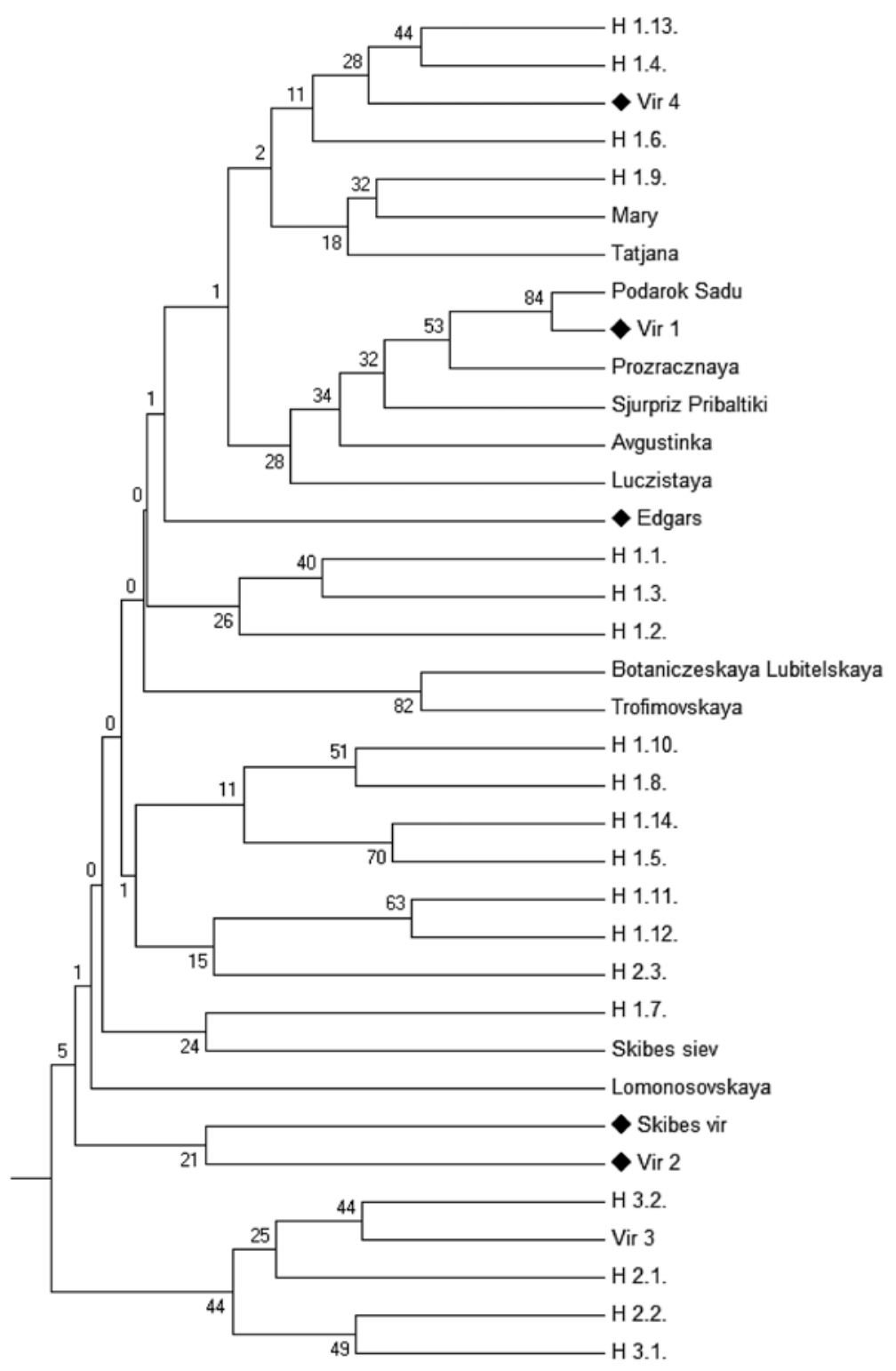

$\longmapsto 0.05$

- sea buckthorn male plants

Figure 1. Genetic relatedness of Latvian sea buckthorn accessions estimated using microsatellite (SSR) molecular markers based on Nei and Li/Dice similarity index and UPGMA (unweighted pair group method with arithmetic mean) clustering 
also was high, ranging from 0.781 ( $\mathrm{HrO7})$ to $0.972(\mathrm{HrO3})$. The fixation index was negative for all loci except $\mathrm{HrO4}$ (0.083) and $\mathrm{HrO}$ (0.016). The probability of identity for these eight tested markers was $7.56 \mathrm{E}-10$, which is the probability that two samples with an identical genotype are in fact unrelated individuals. The length of alleles (in base pairs) was widely distributed for some loci, in particular HrO4 (146-294 bp), HrO7 (168-306 bp) and HrO8 (129-225 bp). High level of polymorphism and good discrimination power was stated also for RAPD markers. The number of bands amplified by each RAPD primer varied from 3 (OPA-02) to 23 (OPD-08), with an average of 12.2 bands per primer (Table 2). Of the total 195 bands, 193 (98.97\%) were polymorphic, with 12.1 polymorphic bands per primer on average. The size of the amplified fragments ranged from 120 to $1500 \mathrm{bp}$, but most were from 300 to $1100 \mathrm{bp}$. The set of RAPD markers used showed much higher level of polymorphism than those used in other investigations with comparable number of markers (Sun et al., 2006).

The high number of detected alleles could be explained by the origin of the tested plant material, which combines accessions of probably diverse genetic background, including cultivars of geographically distant origin (e.g., sea buckthorn accessions collected or developed from the European Hippophae rhamnoides material as well as accessions originated from the Altai region (Siberia) and reciprocal hybrids between these sea buckthorn groups). The same statements as well as the fact, that sea buckthorn is an out-crossing species, could explain the high level of heterozygocity found in this study. The hybrid background could be the reason for large size range of some SSR and RAPD markers. The fixation index of SSR markers was negative for all loci except $\mathrm{HrO} 4$ and $\mathrm{HrO}$, indicating an excess of heterozygotes. However, as these samples were not from natural populations, the deviation from Hardy-Weinberg equilibrium could not be determined.

SSR, RAPD and combined SSR-RAPD data were used in the estimation of genetic diversity and relatedness of Latvian sea buckthorn cultivars. Sea buckthorn accessions showed high genetic diversity. In $99.4 \%$ and $93.4 \%$ of the cases, for SSR and RAPD markers respectively, genetic distances among accessions had values over 0.30 and for both marker types there were no cases with genetic distance value under 0.01 . In the case of SSR markers the average pair-wise value of Nei and Li/Dice similarity indices (Nei, Li, 1979) among sea buckthorn accessions was 0.3998, range 0.0667 to 0.9333 . Higher similarity index values were found for RAPD marker data: 0.6194 in average, range 0.2118 to 0.9048 . The highest similarity value using SSR marker data was found between accessions 'Podarok Sadu' and Vir 1 (distance 0.9333), whereas the lowest between accessions 'Avgustinka' and H 3.1. (0.0667). In the case of RAPD data the highest genetic similarity value was found between cultivars 'Podarok Sadu' and 'Sjurpriz Pribaltiki' (distance 0.9048), and the lowest - between hybrids H 1.2. and H 1.4. (0.2118). The combined SSRRAPD data showed closer accordance with RAPD data - showing the same variety pair for maximal similarity: 'Podarok Sadu' - 'Sjurpriz Pribaltiki' (distance 0.8590) whereas variety pair for minimal similarity was different - H 2.2. and H 1.4. (0.2478).

Nei and Li/Dice similarity matrices acquired from SSR and RAPD molecular marker sets as well as combination of these were used in UPGMA clustering (Figs 1-3). Analysis using SSR data did not identify separated variety groups according to origin of plant material (Fig. 1), probably due to the hybrid nature of the analyzed material. However, several groups of closely related accessions could be marked out. Common grouping was observed for the widely grown cultivars, which have a common place of origin ('Avgustinka', 'Luczistaya', 'Podarok Sadu', 'Prozrachnaya', 'Sjurpriz Pribaltiki'). Close relatedness based on the SSR data was found also for cultivars 'Mary' and 'Tatjana', which are open pollinated seedlings of 'Botaniczeskaya Lubitelskaya'.

RAPD amplification data showed strict separation of sea buckthorn accessions into groups according to geographical origin: cultivars from Moscow State University and their offspring and groups of hybrids from Altai (designed with "H", Fig. 2). The exceptions were cv. 'Mary', which was located distantly from the parental cv. 'Botaniczeskaya Lubitelskaya' and sibling 'Tatjana', as well as $\mathrm{H}$ 1.4., H 1.6. and H 1.8., which were located distantly from other " $\mathrm{H}$ " hybrids. Distant compact group was for male accessions of sea buckthorn (Fig. 2).

As exceptions, we could mention male cultivars 'Edgars' and 'Skibes vir', which showed close relatedness with $\mathrm{H}$ 1.1. accession as well as variety 'Skibes siev'. Accessions 'Skibes vir' and 'Skibes siev' are semi wild or wild growing accessions, collected at the same place, and showed close relatedness also by SSR marker data. Specific bands for male plants were not detected, but combination of presence or absence of particular RAPD bands ensured distant male variety grouping, which was not observed by SSR marker data analysis. This information could be used in the further studies to find out additional gender specific molecular markers for sea buckthorn. There is RAPD-based genderspecific marker already developed in sea buckthorn F1 populations of some particular crosses (Persson, Nybom, 1998). Unfortunately, this marker did not amplify gender specific bands for the tested plant material and was not included in this study. In general, despite serious RAPD marker drawbacks (Sefc et al., 2001), they ensured better characterization of sea buckthorn plant material according to geographical origin and gender.

The total characterization of Latvian sea buckthorn plant material was performed by combined 


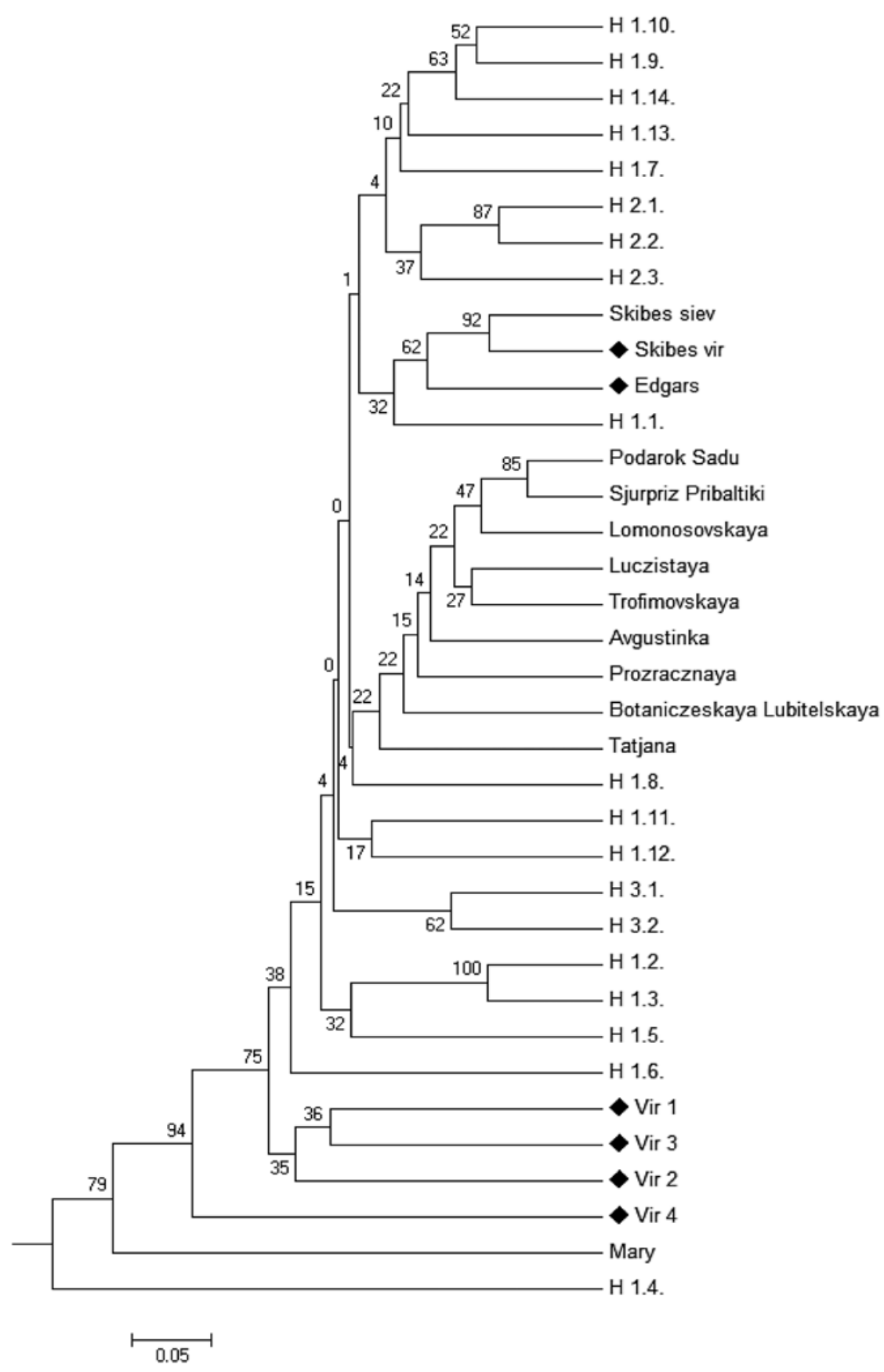

- sea buckthorn male plants

Figure 2. Genetic relatedness of Latvian sea buckthorn accessions estimated using random amplified polymorphic DNA (RAPD) molecular markers based on Nei and Li/Dice similarity index and UPGMA (unweighted pair group method with arithmetic mean) clustering

RAPD and SSR data set. The relatedness of sea buckthorn plant material according to UPGMA clustering for total data set was similar to the distribution using RAPD amplification data (Fig. 3).

Information gathered by SSR markers had only complementary role to ensure more detailed plant material characterization and ensure repeatability and transformability of data (Fig. 3). The number of SSR and RAPD markers used ( 8 and 16 , respectively) could be a reason for better characterization of Latvian sea buckthorn plant material by RAPD marker genotyping that is not typical of dominant ones. In this case selected RAPD markers ensured better genome coverage of tested plant material and thereby higher distinction ability. The SSR markers used have been developed in $H$. rhamnoides ssp. sinensis (Wang et al., 2008), which is not represented in tested sea buckthorn germplasm. Although they showed good applicability and high level of polymorphism, sequence specificity of SSR markers can influence their grouping ability. 


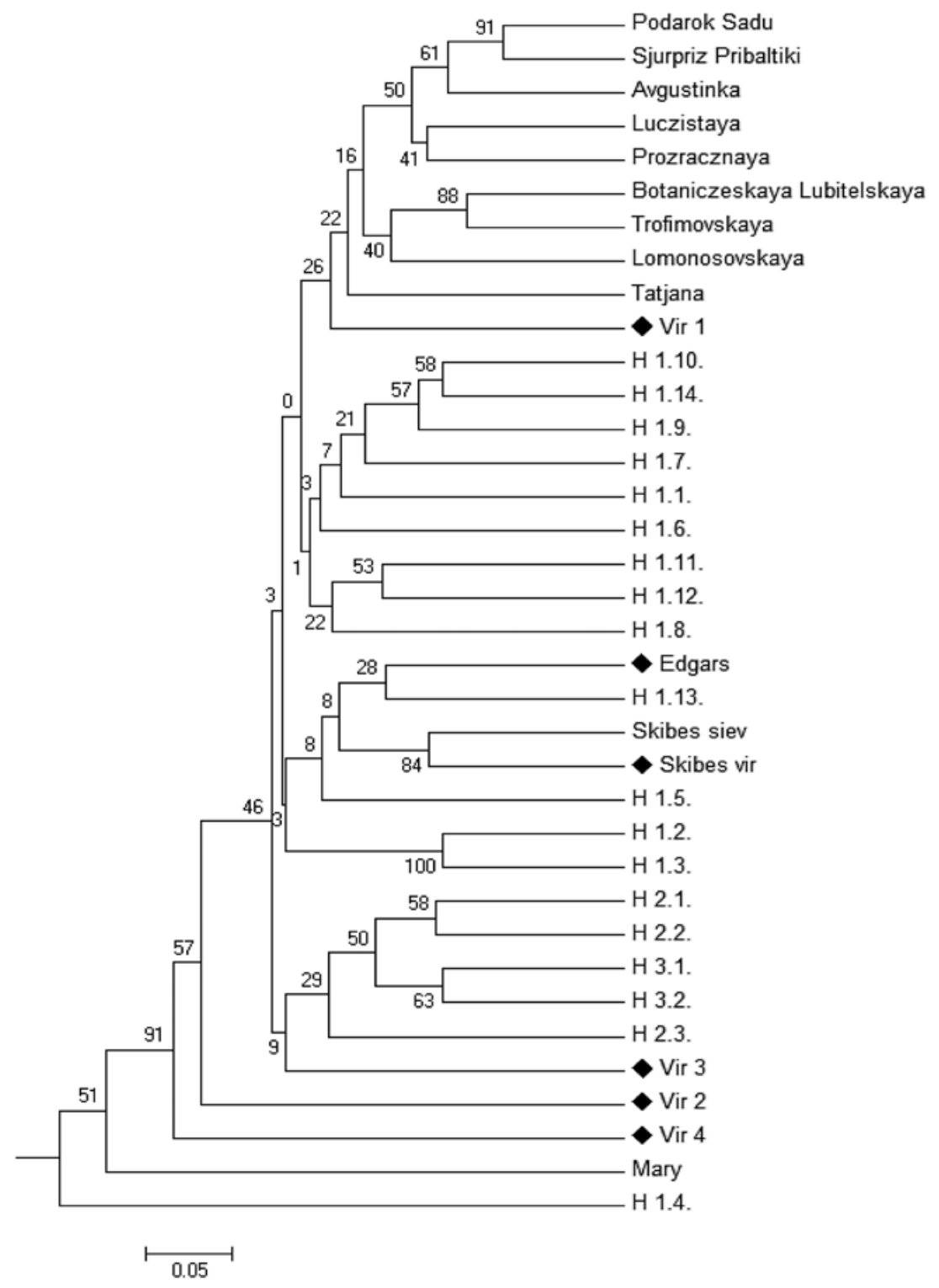

$\checkmark$ - sea buckthorn male plants

Figure 3. Genetic relatedness of Latvian sea buckthorn accessions estimated using microsatellite (SSR) and random amplified polymorphic DNA (RAPD) molecular markers based on Nei and Li/Dice similarity index and UPGMA (unweighted pair group method with arithmetic mean) clustering

\section{Conclusions}

1. Sea buckthorn (Hippophae rhamnoides L.) plant material grown in Latvia has high genetic diversity, as it was confirmed by microsatellite (SSR) and random amplified polymorphic DNA (RAPD) marker data as well as a combination of both.

2. Selected sets of SSR and RAPD markers ensured high level of polymorphism and are suitable for application in different $H$. rhamnoides subspecies, as well as in crosses among $H$. rhamnoides ssp. mongolica, ssp. rhamnoides and ssp. fluviatilis.

3. More adequate grouping of sea buckthorn accessions according to geographical origin and gender was for RAPD markers.

4. Comprehensive sea buckthorn plant material evaluation should be performed using both marker types, because SSRs are species specific markers, which ensure higher repeatability and transformability of data.
5. Combination of data from both marker types could ensure more precise evaluation of genetic diversity and internal relatedness of sea buckthorn plant material.

\section{Acknowledgements}

This research was supported by the Latvia State Research Program No. 9 Innovative technologies for the development of high-value, safe and healthy food products from genetically, physiologically and biochemically various plant and animal material.

Received 23092013

Accepted 20022014

\section{References}

Bartish I. V., Jeppsson N., Bartish G. I., Lu R., Nybom H. 2000. Inter- and intraspecific genetic variation in Hippophae (Elaeagnaceae) investigated by RAPD markers. Plant Systematics and Evolution. 225: 85-101 http://dx.doi.org/10.1007/BF00985460 
Bruvelis A. 2003. Cultivation of sea buckthorn in Baltic States. $1^{\text {st }}$ congress of the International Seabuckthorn Association: Seabuckthorn - a resource of health a challenge to modern technology. Berlin, Germany, p. 64-66

Bruvelis A. 2007. Sea buckthorn Hippophaë rhamnoides L. taxonomy, distribution and introduction in Baltic States. Vegetation of Latvia, 13: 33-38

Hampl V., Pavlicek A., Flegr J. 2001. Construction and bootstrap analysis of DNA fingerprinting-based phylogenetic trees with a freeware program FreeTree: application to trichomonad parasites. International Journal of Systematic and Evolutionary Microbiology, 51: 731-735 http://dx.doi.org/10.1099/00207713-51-3-731

Jeppsson N., Bartish I. V., Persson H. A. 1999. DNA analysis as a tool in sea buckthorn breeding. Janick J. (ed.). Perspectives on new crops and new uses. Alexandria, USA, p. 338-341

Lacis G., Kota I., Rungis D. 2014. Application of SSR markers for the assessment of Latvian sea buckthorn (Hippophae rhamnoides L.) genetic diversity. Singh V. (ed.). Sea buckthorn (Hippophae L.): a multipurpose wonder plant, 4: 157-166

Nei M., Li W. H. 1979. Mathematical model for studying genetic variation in terms of restriction endonucleases. Proceedings of the National Academy of Sciences of the United States of America. 76: 5269-5273 http://dx.doi.org/10.1073/pnas.76.10.5269

Peakall R., Smouse P. E. 2006. GENALEX 6: genetic analysis in Excel. Population genetic software for teaching and research. Molecular Ecology Notes, 6: 288-295 http://dx.doi.org/10.1111/j.1471-8286.2005.01155.x

Persson H. A., Nybom H. 1998. Genetic sex determination and RAPD marker segregation in the dioecious species sea buckthorn (Hippophae rhamnoides L.). Hereditas, 129: 45 $51 \mathrm{http}: / / \mathrm{dx}$.doi.org/10.1111/j.1601-5223.1998.00045.x

Ruan C., Li D. 2005. AFLP fingerprinting analysis of some cultivated varieties of sea buckthorn (Hippophae rhamnoides). Journal of Genetics, 84 (3): 311-316 http://dx.doi.org/10.1007/BF02715802

Ruan C., Qin P., Zheng J., He Z. 2004. Genetic relationships among some cultivars of sea buckthorn from China, Russia and Mongolia based on RAPD analysis. Scientia
Horticulturae. 101: 417-426

http://dx.doi.org/10.1016/j.scienta.2003.11.013

Sefc K. M., Lefort F., Grando M. S., Scott K. D., Steinkellner H., Thomas M. R. 2001. Microsatellite markers for grapevine: a state of the art. Roubelakis-Angelakis K. A. (ed.). Molecular biology and biotechnology of grapevine. Dordrecht, the Netherlands, p. 1-30

Sheng H. M., An L. Z., Chen T., Xu S. J., Liu G. X., Zheng X. L., Pu L. L., Liu Y. J., Lian Y. S. 2006. Analysis of the genetic diversity and relationships among and within species of Hippophae (Elaeagnaceae) based on RAPD markers. Plant Systematics and Evolution, 260: 26-37 http://dx.doi.org/10.1007/s00606-006-0413-1

Singh R., Mishra S. N., Dwivedi S. K., Ahmed Z. 2006. Genetic variation in seabuckthorn (Hippophae rhamnoides L.) populations of cold arid Ladakh (India) using RAPD markers. Current Science, 91 (10): 1321-1322

Sun K., Chen W., Ma R., Chen X., Li A., Ge S. 2006. Genetic variation in Hippophae rhamnoides ssp. sinensis (Elaeagnaceae) revealed by RAPD markers. Biochemical Genetics. 44 (5-6): 186-197 http://dx.doi.org/10.1007/s10528-006-9025-2

Tamura K., Stecher G., Peterson D., Filipski A., Kumar S. 2013. MEGA6: molecular evolutionary genetics analysis, version 6.0. Molecular Biology and Evolution, 30: 27252729 http://dx.doi.org/10.1093/molbev/mst197

Tian C., Lei Y., Shi S., Nan P., Chen J., Zhong Y. 2004 (a). Genetic diversity of sea buckthorn(Hippophaerhamnoides) populations in northeastern and northwestern China as revealed by ISSR markers. New Forest, 27: 229-237 http://dx.doi.org/10.1023/B:NEFO.0000022224.59436.7a

Tian C., Nan P., Shi S., Chen J., Zhong Y. 2004 (b). Molecular genetic variation in Chinese populations of three subspecies of Hippophae rhamnoides. Biochemical Genetics, 42 (78): $259-267$ http://dx.doi.org/10.1023/B:BIGI.0000034430.93055.ff

Wang A., Zhang Q., Wan D., Yang Y., Liu J. 2008. Nine microsatellite DNA primers for Hippophae rhamnoides ssp. sinensis (Elaeagnaceae). Conservation Genetics, 9: 969-971 http://dx.doi.org/10.1007/s10592-007-9416-x

ISSN 1392-3196 / e-ISSN 2335-8947

Zemdirbyste-Agriculture, vol. 101, No. 3 (2014), p. 333-340

DOI $10.13080 / \mathrm{z}-\mathrm{a} .2014 .101 .043$

\title{
Dygliuotojo šaltalankio (Hippophae rhamnoides L.) latviškos pradinès selekcinès medžiagos genetinès įvairovès įvertinimas naudojant molekulinius žymeklius
}

\author{
G. Lācis, I. Kota-Dombrovska \\ Latvijos valstybinis vaisių auginimo institutas
}

\section{Santrauka}

Dėl didelès vertingų maistingų ir biologiškai aktyvių medžiagų koncentracijos dygliuotasis šaltalankis (Hippophae rhamnoides L.) Latvijoje tampa ịdomiu ir perspektyviu augalu. Didejjantis jo panaudojimas sodininkysteje ir daržininkysteje mokslininkus bei selekcininkus skatina kurti įvairias šaltalankio formas, skirtas auginti vaisiams. Siekiant gauti gerai prisitaikiusias ir vertingas veisles augalinė medžiaga, gauta sukryžminus $H$. rhamnoides ssp. mongolica, ssp. rhamnoides ir ssp. fluviatilis, buvo introdukuota ir sukurta Latvijoje. Turimos šaltalankio augalinès medžiagos panaudojimas priklauso nuo tinkamo genetinès įvairovès įvertinimo ir tėvinès augalinès medžiagos identifikavimo. Šiuo tikslu buvo apibūdinti 36 šaltalankio genotipai, naudojant anksčiau ištirtus 8 miksrosatelitinius arba paprastujų pasikartojančių sekų (PPS) ir 16 atsitiktinai amplifikuotų polimorfinių DNR (AAPD) žymeklių. Panaudoti žymekliai leido atskirti tirtus šaltalankio genotipus ir nustatyti jų genetinị panašumą bei giminingumą. Nustatyta koreliacija tarp klasterinès molekulinių žymeklių analizės duomenų ir augalinės medžiagos kilmès; tai parodè panaudotų žymeklių tinkamumą apibūdinant šaltalankio pradinę selekcinę medžiagą. Didesnis atitikimas su žinoma kilme nustatytas naudojant AAPD žymeklius, kurie šaltalankio genotipus suskirste pagal kilmės vietą ir selekcinę programą. Šie du taikyti molekulinių žymeklių metodai papildè vienas kitą ir suteikè genetinès informacijos Latvijos šaltalankio selekcininkams, kurie ją panaudos kurdami tolesnę hibridizacijos/kryžminimo strategiją, be to, padès vykdyti žymekliais paremtą selekciją.

Reikšminiai žodžiai: AAPD, genetinè ịvairovè, Hippophae rhamnoides, mikrosatelitai, pradinė selekcinè medžiaga. 